\title{
Adaptation to Climate Change in Coffee Production Systems in Tolima
}

\author{
Diana Canal-Daza ${ }^{1}$ (D), Hernán Andrade-Castañeda ${ }^{1}$ \\ ${ }^{1}$ Universidad del Tolima - UT, Ibague/Tolima, Colômbia
}

\begin{abstract}
It was estimated the climate change adaptation of the main coffee production systems in Líbano, Tolima, Colombia, using diversity indicators. Three production systems were selected: agroforestry systems (AFS) with Cordia alliodora, AFS with plantain and in monoculture, with four replications, locating five sampling units to collect and identify the ant genera as diversity and adaptation indicators. The richness index of Margalef detected between systems ( 1.3 vs 0.6 vs 0.6 for AFS with C. alliodora, monoculure and AFS with plantain, respectively). The genera Cephalotes, Dorymyrmex, Hypoponera, Pachycondyla, Octostruma and Proceratium, which require abundant biomass and litter, were registered just in AFS with C. alliodora, coinciding with the depth of this layer. The AFS with C. alliodora present advantages due they improve conditions for the conservation of several groups of ants, which are indicators of diversity and climate change adaptation.
\end{abstract}

Keywords: diversity, litter, ants, agroforestry systems. 


\section{INTRODUCTION}

The current climate change in the planet is accelerated by anthropic activity, mostly given by the increase in the emission of greenhouse gases (GHG) caused by land use, deforestation, use of fossil fuels, cement production and the agricultural production (Intergovernmental Panel on Climate Change [IPCC], 2002). This world-wide phenomenon notoriously affects the biological diversity of ecosystems due to the loss of habitats and landscape fragmentation (Uribe, 2015). In this context, adaptation is one of the strategies presented by the international community to face climate change (IPCC, 2007).

Adaptation is the adjustment of human or natural systems in response to real or expected climate stimuli, which attenuates harmful effects or exploits beneficial opportunities (IPCC, 2007). Three types of adaptation can be noted: anticipative, autonomous and planned (Magrin, 2015). Given that one of the main reasons of diversity loss is climate change, some effects are foreseen to make even harder the conservation of species and ecosystems (Toranza et al., 2016; Fung, et al., 2017). Therefore, some measurements must be implemented aiming to give a sustainable management to the planet considering the adaptation needs of the organisms to the climate change (MAGRAMA, 2016). Preserve ecosystems, their biodiversity and ecosystem services is a full strategy that helps adapting to climate change (EEM, 2003). This strategy generates not only social and economic benefits, but also contributes to preserve the diversity of plant and animal species (UICN, 2012).

Agroforestry systems (AFS) are considered as one of these alternatives, given that their main goal is to diversify and optimize production keeping trees that comply countless purposes, such as production and generation of services (Schroth et al., 2000; Casanova-Lugo et al., 2011). Rivera \& Armbrecht (2005) mention that modifications made to the traditional production in AFS with native trees generate significant changes in terms of planned and associated diversity, including insects, plants and animals. Associated fauna is very important in natural or agricultural systems. With the reduction of shade, there is also a reduction of fauna that is potentially beneficial for the production system (Gallego et al., 2009).
Coffee is the second product in commercialization importance after petroleum. It is one of the most popular beverages, considering that for 2011 it was estimated an annual production of 6,3 million tons (Naranjo et al., 2011). García et al. (2015) claim that one of the most common production systems in neo-tropic landscapes is shaded coffee, which has an important role in the conservation of biological diversity, provided that it can keep species depending on forests in areas affected by deforestation (Jeseer \& Verweij, 2015). Besides, these diversified shaded coffee areas can work as biological corridors, increasing the buffer areas around natural reserves and improving value and preservation of forested patches (García et al., 2015). Just the same, a clear difference between production systems under direct sunlight or under specialized shade in contrast with traditional shade has been found, since shade trees represent an important shelter for biodiversity, and several groups of Hymenoptera, Coleoptera and Lepidoptera may reach high levels of diversity (Perfecto et al., 1996).

A great number of hunting ant species are found in litter and soil of natural forests and agro-ecosystems (Rivera \& Armbrecht, 2005). Given the diversity of these organisms - constituted by demographically rare species -, and the high trophic and ecological specialization that this type of ant shows, it could be predicted that its assembly will be strongly affected when there are drastic changes in the habitat (Armbrecht et al., 2008; Abadía et al., 2010). Ants dominate most ecosystems in the Earth, from tundra to tropical forests, interact with many other organisms and, consequently, participate in the functional processes of the ecosystems, like regulation of the abundance of other arthropods. Hence it is clear the importance of this group as a change indicator in the different types of habitat (Perfecto et al., 2003; Philpott \& Armbrecht, 2006; Jiménez et al., 2008).

Despite there is research literature reporting diversity of different taxonomical groups in land use, there are no documents referring this diversity to the climate change adaptation, neither to which coffee production system can adapt the most to this environmental problem. This paper intends to estimate the capacity of adaptation to climate change that different coffee production systems have, taking as indicators the diversity of ant genera and litter depth. 


\section{MATERIALS AND METHODS}

The study was developed in coffee farms located in several vicinities of the municipality of Líbano, Tolima (Colombia) (Figure 1). The city is at a mean altitude of $1565 \mathrm{~m}$, has a mean rainfall of $2235 \mathrm{~mm} /$ year and a temperate-humid climate with a mean temperature of $19.1{ }^{\circ} \mathrm{C}$ (IDEAM, 2010). This municipality was selected for being located among the ones with the highest percentage of coffee crops area: $7.9 \%$ of the total of the farmable area of the municipality in 2014 (FNC, 2014).

Dominant coffee production systems were selected: 1) coffee in monocrop;2) SAF with plantain shade (Musa AAB); and 3) SAF with Spanish elm (Cordia alliodora) without certification. Four plots or farms were evaluated per treatment, which constituted the repetitions for a total of 12 experimental units.

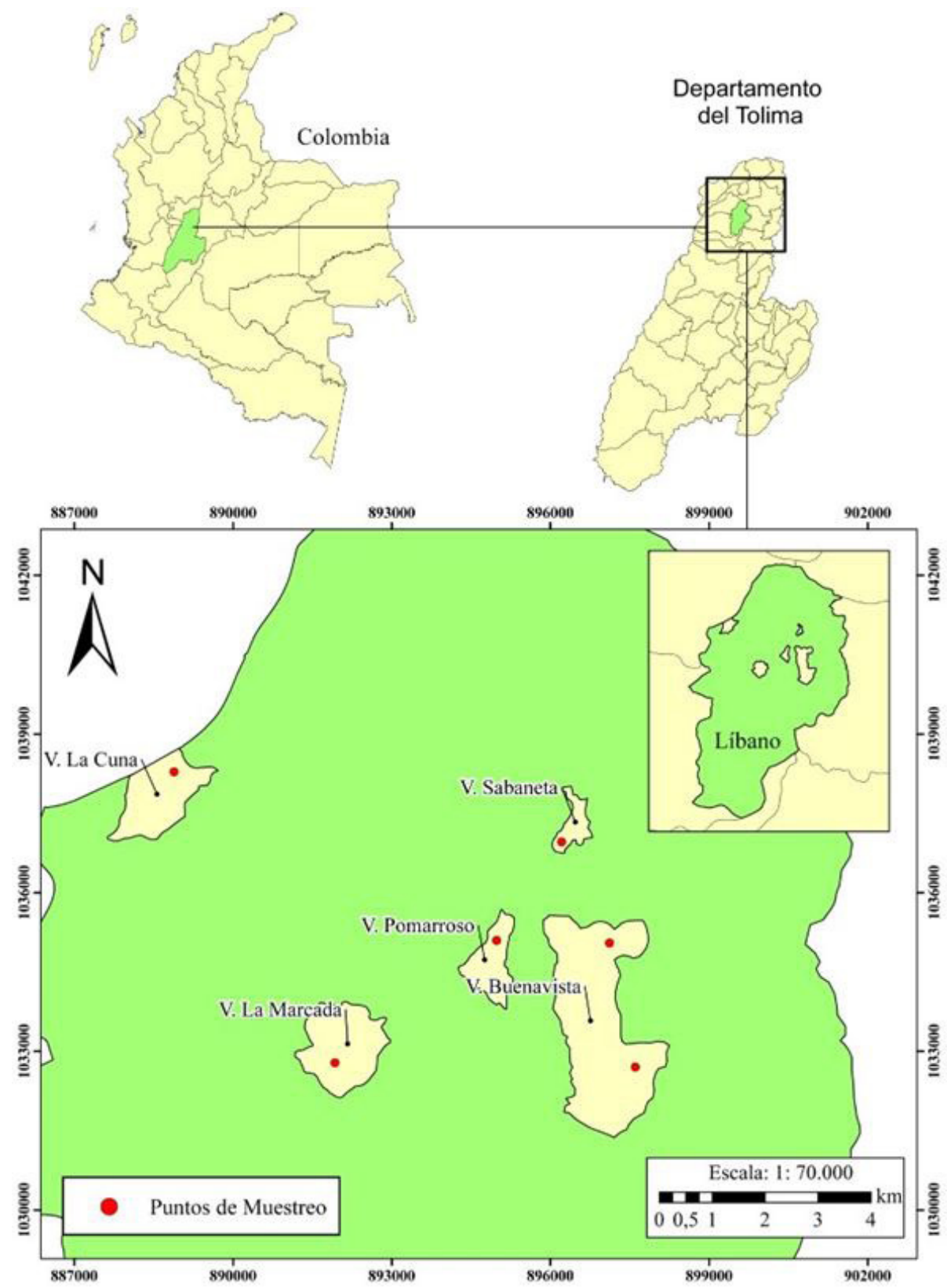

Figure 1. Location of the study area. Líbano, Tolima, Colombia. 
Adaptation to climate change in coffee production systems was estimated as the capacity of studied systems to shelter ant diversity, considered as a taxonomic group indicator of the system diversity. In every plot or repetition five sampling units of $1 \mathrm{~m}^{2}$ each were located to carry out diversity analysis by following this procedure:

- Depth of litter was randomly measured in five places per sampling unit, using a graded ruler.

- For 20 min, branches, trunks and litter were examined and all ant individuals foraging at the moment were collected in the sampling unit.

- Litter present in the sampling unit was sifted and put in mini-Winkler sacks for $48 \mathrm{~h}$ for extraction of ants found, according to ALL protocol (Ants of the Leaf Litter Protocol) (Agosti et al., 2000).

- Ants found in the collection and the sacks were stored in alcohol at 70\% for later identification, which was made with the support of the Entomology Laboratory of Universidad del Tolima. The identification was made to the genus level, using the keys of Palacio \& Fernández (2003) and Fernández \& Palacio (2006).

The diversity of ants was assessed making curves of accumulation of species with the help of the software Estimates version 8.2 (Colwell, 2009). Shannon-Wiener $\left(\mathrm{H}^{\prime}\right)$, Simpson $(\mathrm{K})$ and Margaleff diversity indexes were estimated with the free software Paleontological Statistics version 2.17 (Hammer et al., 2001). The Kruskal-Wallis non-parametric statistical test was carried out to verify if there were significant differences concerning the diversity of ants in the coffee production systems assessed.

\section{RESULTS AND DISCUSSION}

Species accumulation curve (Figure 2) based on ACE Mean, Chao 1 and Jack 1 estimators, show a good representativeness of the sampling carried out in the three systems of coffee productions. Even though it was not possible to take it to the ideal level of representativeness, between $77 \%$ and $82 \%$ of the expected ant genera was reached. These estimators base their results on the number of species or genera less abundant (unique and duplicated), showing a good quality of the samplings carried out.
A total of 1888 ant individuals were collected, represented in eight sub-families (Dolichoderinae, Dorylinae, Ectatominae, Formicinae, Myrmicinae, Ponerinae, Proceratiinae and Pseudomyrmicinae) and 24 genera, in $60 \mathrm{~m}^{2}$ of sampling area. Myrmicinae subfamily was the most representative as for number of genera present (eight in total) and to the number of individuals (78.5\% of the total collected), followed by Formicinae subfamily (14.6\% of the total of individuals) (Figure 3). Rivera \& Armbrecht (2005) reported the Myrmicinae and Formicidae subfamilies

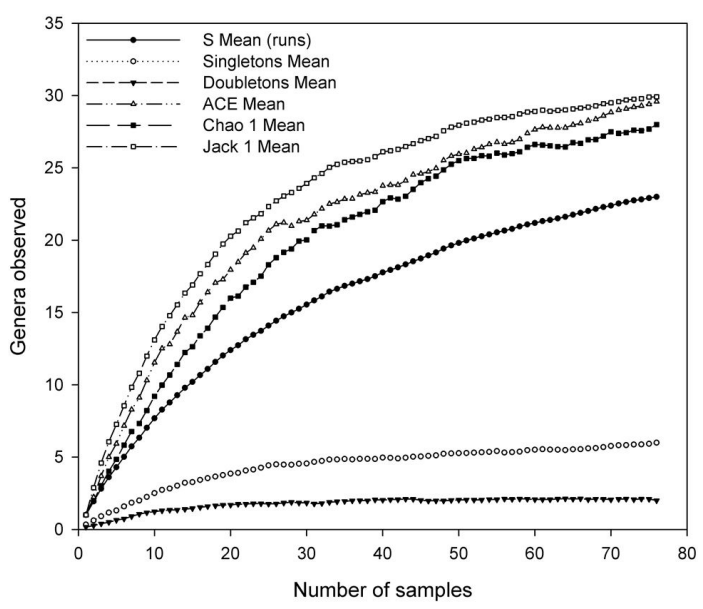

Figure 2. Ant species accumulation curve (genera) in coffee production systems in Líbano, Tolima, Colombia.

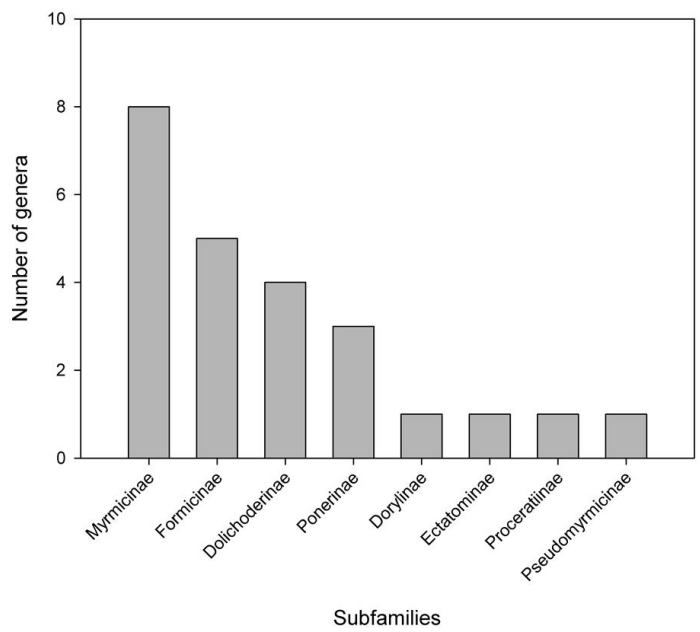

Figure 3. Number of ant genera per subfamily found in the most dominant coffee production systems in Líbano, Tolima, Colombia. AFS-C. alliodora: agroforestry systems associated with C. alliodora, AFS-Plantain: agroforestry systems associated with plantain. Values with different letters show statistical differences $(\mathrm{p}<0.05)$. 
(64\% and 22\%, respectively) as the most abundant in shaded and under sunlight coffee plantations in Risaralda, Colombia. The Myrmicinae subfamily has a high representativeness in coffee landscapes in the Colombian Andean area, specifically in Valle del Cauca, Antioquia and Santander (Clavijo et al., 2008).

Solenopsis genus showed the highest abundance, taking $69 \%$ of the total collected, followed by genera Paratrechina and Mymelachista with a representation of $7 \%$ and $6 \%$, respectively. This result matches with different studies where species of the Solenopsis genus are reported as the most abundant in these agro-ecosystems (Barbera et al., 2002; Rivera \& Armbrecht, 2005; Varón et al., 2007; Zabala et al., 2013). Most species of Solenospsis genus are classified in the trophic guild of omnivorous ground-dominant ants, have subterranean nests, are big colonies and generalist concerning food choices (Silvestre et al., 2003).

Simpson and Shannon Wiener indexes, which measure dominance and equity, did not present significant differences $(p>0.05)$ between the three systems evaluated. In contrast, the Margalef index of richness showed significant differences $(\mathrm{p}<0.05)$ : $1.3 \pm 0.2$ vs $0.6 \pm 0.2$ vs $0.6 \pm 0.2$ in AFS with C. alliodora, monocrop coffee plantations and AFS with plantain, respectively (Figure 4). The number of genera was also contrasting between production systems: AFS with C. alliodora had 18, in monocrops there were reported 12 genera and in the AFS with plantain only nine.

The Cephalotes, Dorymyrmex, Hypoponera, Pachycondyla, Octostruma and Proceratium genera were found exclusively in the AFS with C. alliodora, showing the relevance of these trees in the conservation of biodiversity. Rivera \& Armbrecht (2005) reported the highest richness of species in poly-generic systems or with some type of shade, compared to systems of monocrop production; in the first ones were found up to nine species of exclusive ants. Armbrecht et al. (2005) highlight the capacity of AFS with coffee to shelter a higher richness of ant species, being their trophic guild assembles the most similar to those of the forest patches.

AFS with C. alliodora and plantain shared the presence of some genera such as Crematogaster, Cyphomyrmex, Gnamptogenys and Paratrechina. These genera, registered exclusively in AFS and not in monocrop coffee plantations, are classified

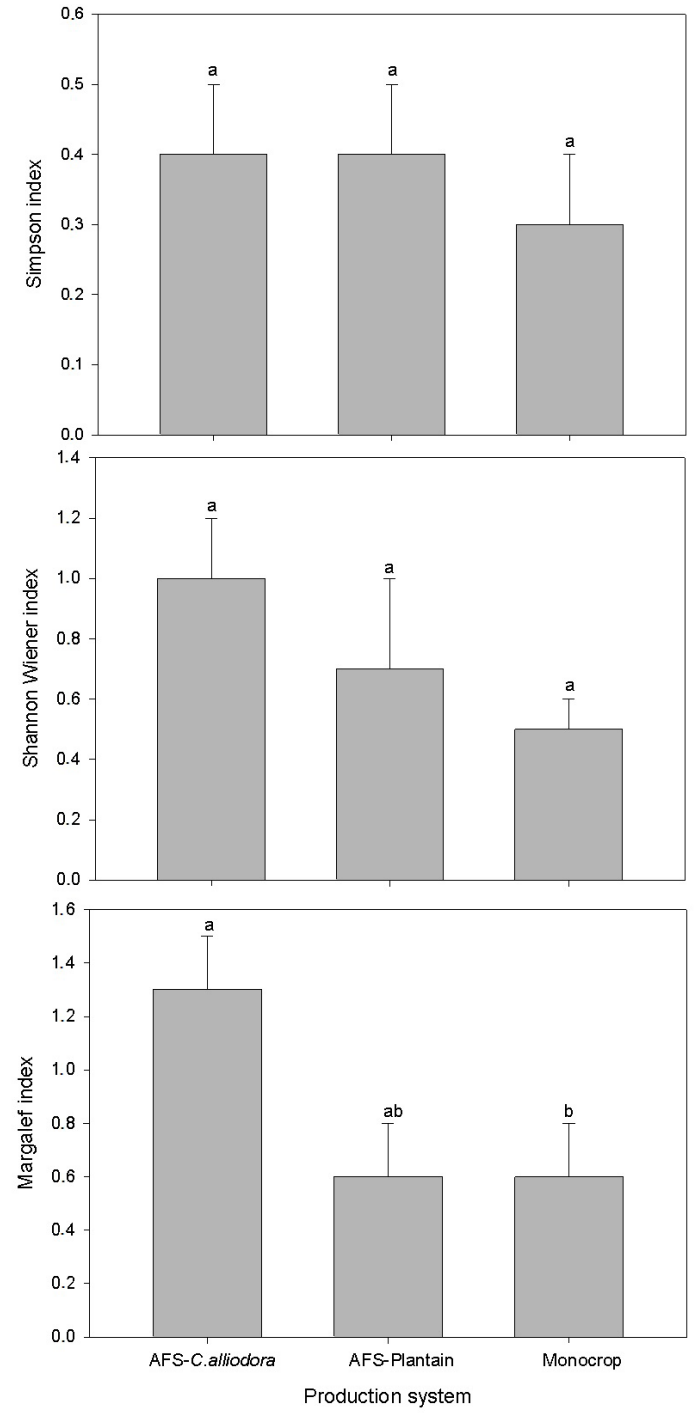

Figure 4. Ant diversity indexes in three coffee production systems in the municipality of Líbano, Tolima, Colombia. AFS-C. alliodora: agroforestry systems associated with $C$. alliodora, AFS-Plantain: agroforestry systems associated with plantain.

by Silvestre et al. (2003) as ant trophic guilds with special features such as specialized predatory cryptic ponies, minimal vegetation specialists, specialized predatory cryptic myrmecines, fungi-sowing cryptic atinae. Because of their feeding habits or their type of organization, these trophic guilds group species require more complex systems with high litter and soil biomass and diversity of other organisms. The same authors state that an example of this can be observed in the Hypoponera and Gnamptogenys genera, while 
in the genus Brachymyrmex it is considered a good indicator for areas in recovery.

Features of the ant trophic guilds present exclusively in the AFS tested match the depth of the litter layer (Figure 5), which was statistically different $(\mathrm{p}<0.05)$ among the coffee production systems. AFS with C. alliodora present a higher layer of litter on the ground than the plantain SAF and monocrop coffee ( 8.9 vs 3.4 vs $1.5 \mathrm{~cm}$, respectively; Figure 5). Rivera \& Armbrecht (2005) found that shade creates climatic and environmental conditions that favor diversity and presence of some ant trophic guilds, increasing the similarity of AFS with forest ecosystems.

Armbrecht et al. (2006) state that intensification of coffee production systems leads to the loss of related fauna; in the case of ants, nesting resources become limited. Anthropogenic changes that turn habitats into areas of agricultural and livestock production alter so strongly the ecological processes that they cause loss of animal and plant diversity. On this matter, multi-stratum AFS, given its higher similarity with ecosystems, can work as bridges or corridors that minimize such effect (Francesconi \& Montagnini 2015). The implementation of AFS favors the presence of ant groups that help the crop and eventually can behave as biological controllers, such as Crematogaster, an important genus that is usually found exclusively in coffee crops associated with trees (Gallego et al., 2009).

When AFS are implemented, species and diversity conservation is favored, becoming an important measure of climate change adaptation (UICN, 2012).

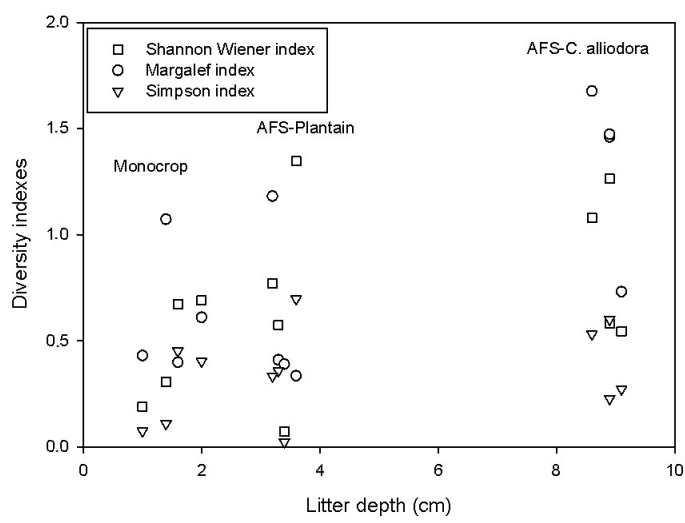

Figure 5. Relationship between ant diversity and litter depth in the dominant coffee production systems in Líbano, Tolima, Colombia.
Species diversity is crucial for the good performance of ecosystems, since deforestation and changes of land use contribute to extinction rates of the species to get higher every time. Climatic change has an accelerating effect of extinction of species in their habitats, generates a very fast change and does not give time for species to adapt (Uribe, 2015). One of the main forms of adaptation is the migration of species to areas with similar conditions to those of their natural habitat (IPCC, 2002; Rodríguez \& Mance, 2009). AFS with coffee have shown habitat and micro-climate similarities with natural ecosystems, which gives them the capacity to favor the diversity of birds and arthropod species and promote adaptation of the species (Chait, 2015).

Philpott et al. (2008) show that intensification of coffee production systems influences directly on the richness and diversity of birds and ants: AFS with native trees favor adaptation and conservations of these species. AFS are important to provide shelter and rest, especially to migrating birds of high importance in the cycles of ecosystems (McDermott \& Rodewald, 2014). Just the same, Caudill et al. (2014) recommend AFS with coffee as strategy to preserve mammal diversity because, even though they do not substitute the native forest, they can provide habitat for small mammals. Studies on AFS show the importance of the use of trees associated to crops, since they are a connectivity element between natural systems, favoring displacement and keeping the diversity of mammals (Cassano et al., 2014).

\section{CONCLUSIONS}

AFS with C. alliodora harbored a higher number of genera of ants, many of which are dominant in systems with abundant and varied vegetation and with big layers of litter. These conditions give ants nesting and feeding conditions similar to those of natural ecosystems.

Agricultural production systems environmentalfriendly managed, in association with native trees, are a great resource to implement programs of climate-change adaptation. Including native trees favors producers economically and increases the places for shelter and the minimal survival conditions, similar to those of natural ecosystems for the different groups of animals to be able to adapt to the changes. 


\section{ACKNOWLEDGEMENTS}

Los autores expresan sus agradecimientos a la Oficina Central de Investigaciones de la Universidad del Tolima, por la financiación del proyecto 80111 en el marco del cual se desarrollo esta investigación. A los productores de café del municipio de Líbano Tolima - Colombia, por permitirnos realizar el trabajo de campo en sus predios.

\section{SUBMISSION STATUS}

Received: 23 nov., 2017

Accepted:12 jul., 2018

\section{CORRESPONDENCE TO}

\section{Diana Canal Daza}

Universidad del Tolima - UT, Calle 42, Santa Helena, Parte Alta, Código Postal 730006299, Ibague/Tolima, Colômbia e-mail: dscanal@ut.edu.co

\section{FINANCIAL SUPPORT}

Oficina Central de Investigaciones de la Universidad del Tolima - Project 80111

\section{REFERENCES}

Abadía J, Bermúdez C, Lozano F, Chacón P. Hormigas cazadoras en un paisaje subandino de Colombia: riqueza, composición y especies indicadoras. Revista Colombiana de Entomologia 2010; 36(1): 127-134.

Agosti D, Majer J, Alonso L, Shultz T. Ants: standard methods for measuring and monitoring biodiversity. Washington; London: Smithsonian Institution; 2000.

Armbrecht I, Chacón P, Gallego M, Rivera L. Efecto de la tecnificación del cultivo de café sobre las hormigas cazadoras de Risaralda. In: Jiménez E, Fernández F, Arias M, Lozano F, editores. Sistemática, biogeografía y conservación de las hormigas cazadoras de Colombia. Bogotá: Instituto de Investigación de Recursos Biológicos Alexander Von Humboldt; 2008. p. 479-496.

Armbrecht I, Perfecto I, Silverman E. Limitation of nesting resources for ants in Colombian forests and coffee plantations. Ecological Entomology 2006; 31(5): 403-410. http://dx.doi.org/10.1111/j.1365-2311.2006.00802.x.

Armbrecht I, Rivera L, Perfecto I. Reduced diversity and complexity in the leaf-litter ant assemblage of Colombian coffee plantations. Conservation Biology 2005; 19(3): 897907. http://dx.doi.org/10.1111/j.1523-1739.2005.00062.x.

Barbera N, Hilje L, Hanson P, Longino J, Carballo M, De Melo E. Diversidad de hormigas en sistemas agroforestales de café contrastantes, en Costa Rica. Agroforestería en las Américas 2002; 9(35): 75-80.

Casanova-Lugo F, Petit-Aldana J, Solorio-Sánchez J. Los sistemas agroforestales como alternativa a la captura de carbono en el trópico mexicano. Revista Chapingo Serie Ciencias Forestales y del Ambiente 2011; 17(1): 133-143. http://dx.doi.org/10.5154/r.rchscfa.2010.08.047.

Cassano C, Barlow J, Pardini R. Forest loss management intensification? Identifying causes of mammal decline in cacao agroforests. Biological Conservation 2014; 169: 14-22. http://dx.doi.org/10.1016/j.biocon.2013.10.006.

Caudill S, DeClerck F, Husband T. Connecting sustainable agriculture and wildlife conservation: Does shade provide habitat for mammals? Agriculture, Ecosystems \& Environment 2014; 199: 85-93. http://dx.doi.org/10.1016/j. agee.2014.08.023.

Chait G. Café en Colombia: servicios ecosistémicos, conservación de la biodiversidad. In: Montagnini F, Somarriba E, Murgueitio E, Fassola H, Eibl B, editores. Sistemas agroforestales, funciones productivas, socioeconómicas y ambientales. Turrialba: CATIE; 2015. p. 349-364.

Clavijo L, Durán S, Vélez J, García R, Botero J. Estudios regionales de biodiversidad en las zonas cafeteras de Colombia - avances técnico cenicafé. Colômbia: Federación Nacional de Cafeteros; 2008.

Colwell R. Estimates: statistical estimation of species richness and shared species from samples. Versión 8.2 [online]. 2009 [cited 2017 Nov 23]. Available from: http://viceroy.eeb. uconn.edu/estimates

Evaluación de los Ecosistemas del Milenio - EEM. Ecosistemas y bienestar humano - Informe del grupo de trabajo sobre el marco conceptual de la evaluación del milenio. Washington: World Resources Institute; 2003.

Federación Nacional de Cafeteros - FNC. Informe de comités departamentales, por la caficultura que queremos. Colômbia: FNC; 2014. 154 p.

Fernández F, Palacio E. Familia Formicidae. In: Fernández F, Sharkey M, editores. Introducción a los hymenoptera de la región Neotropical. Bogotá: Editora Guadalupe; 2006. p. 521-538.

Francesconi W, Montagnini F. Los SAF como estrategia para favorecer la conectividad funcional del paisaje fragmentado. In: Montagnini F, Somarriba E, Murgueito E, Fassola H, Eibil B, editores. Sistemas agroforestales Funciones productivas, socioeconómicas y ambientales. Costa Rica: Editorial CIPAV; 2015. p. 363-380.

Fung E, Imbach P, Corrales L, Vilchez S, Zamora N, Argotty $\mathrm{F}$ et al. Mapping conservation priorities and connectivity pathways under climate change for tropical 
ecosystems. Climatic Change 2017; 141(1): 77-92. http:// dx.doi.org/10.1007/s10584-016-1789-8.

Gallego C, Montoya J, Armbrecht I. ¿Es la sombra benéfica para la diversidad de hormigas y peso del café? Una experiencia en Pescador, Cauca, Colombia. Boletín Científico Centro de Museos. Museo de Historia Natural 2009; 13(2): 2016-2116.

García LV, Luna M, López R. Estructura y diversidad arbórea en sistemas agroforestales de café en la sierra Atoyac, Veracruz. Madera y Bosques 2015; 21(3): 69-82.

Hammer $\check{R}$, Harper D, Ryan P. PAST: Paleontological statistics software package for education and data analysis [online]. 2001 [cited 2017 Nov 23]. Available from: http:// nhm2.uio.no/norlex/past/download.html

Instituto de Hidrología - IDEAM. Meteorología y Estudios Ambientales - Cambio climático en Colombia [online]. Colômbia: IDEAM; 2010 [cited 2017 Nov 23]. Available from: http//www.derechoambientalcolombiano.org/Assets/ PDFs/ICDA-Generalidades_CC_Ideam.pdf

Jeseer R, Verweij P. Café en sistemas agroforestales - Doble dividendo para la biodiversidad y los pequeños agricultores en Perú. The Hague: Hivos; 2015.

Jiménez E, Fernández F, Arias T, Lozano-Zambrano F. Sistemática, biogeografía y conservación de las hormigas cazadoras de Colombia. Bogotá: Instituto de Investigación de Recursos Biológicos Alexander von Humboldt; 2008.

Magrin G. Adaptación al cambio climático en América Latina y el Caribe. Santiago de Chile: Naciones Unidas; Comisión Económica para América Latina y el Caribe; 2015.

McDermott M, Rodewald A. Conservation value of silvopastures to Neotropical migrants in Andean forest flocks. Biological Conservation 2014; 175: 140-147. http:// dx.doi.org/10.1016/j.biocon.2014.04.027.

Ministerio de Agricultura, Alimentación y Medio Ambiente - MAGRAMA. Biodiversidad y cambio climático [online]. Madrid: MAGRAMA; 2016 [cited 2017 Nov 23]. Available from: http://www.magrama.gob.es/es/biodiversidad/ temas/conservacion-de-la-biodiversidad/biodiversidady-cambio-climatico

Naranjo M, Vélez L, Rojano B. Actividad antioxidante de café colombiano de diferentes calidades. Revista Cubana de Plantas Medicinales 2011; 16(2): 164-173.

Palacio E, Fernández F. Claves para subfamilias y géneros. In: Fernández F, editor. Introducción a las hormigas de la región Neotropical. Bogotá: Instituto de Investigación de Recursos Biológicos Alexander Von Humboldt; 2003. p. 233-260.

Panel Intergubernamental de Cambio Climático - IPCC. Cambio climático y biodiversidad. Ginebra: IPCC; 2002. (Documento técnico; V).

Panel Intergubernamental de Cambio Climático IPCC. Climate Change 2007 - The Physical Science Basis Contribution of Working Group I to the Fourth Assessment Report of the IPCC; 2007.
Perfecto I, Mas A, Dietsch T, Vandermeer J. Conservation of biodiversity in coffee agroecosystems a tri-taxa comparison in Southern Mexico. Biodiversity and Conservation 2003; 12(6): 1239-1252. http://dx.doi.org/10.1023/A:1023039921916.

Perfecto I, Rice R, Greenberg R, Van der Voort M. Shade coffee: a disappearing refuge for biodiversity. Bioscience 1996; 46(8): 598-608. http://dx.doi.org/10.2307/1312989.

Philpott SM, Arendt WJ, Armbrecht I, Bichier P, Diestch TV, Gordon C et al. Biodiversity loss in Latin American coffee landscapes: review of the evidence on ants, birds and trees. Conservation Biology 2008; 22(5): 1093-1105. http://dx.doi.org/10.1111/j.1523-1739.2008.01029.x. PMid:18759777.

Philpott SM, Armbrecht I. Biodiversity in tropical agroforests and the ecological role of ants and ant diversity in predatory function. Ecological Entomology 2006; 31(4): 369-377. http://dx.doi.org/10.1111/j.1365-2311.2006.00793.x.

Rivera L, Armbrecht I. Diversidad de tres gremios de hormigas en cafetales de sombra, de sol y bosques en risaralda. Revista Colombiana de Entomologia 2005; 31(1): 89-86.

Rodríguez M, Mance H. Cambio climático: lo que está en juego. Bogotá: Dupligráficas; Foro Nacional Ambiental; 2009.

Schroth G, Krauss U, Gasparotto L, Aguilar JD, Vohland $K$. Pests and diseases in agroforestry system of the humid tropics. Agroforestry Systems 2000; 50(4): 199-241. http:// dx.doi.org/10.1023/A:1006468103914.

Silvestre R, Brandao C, Silva R. Grupos funcionales de hormigas: el caso de los gremios del Cerrado. In: Fernández F, editor. Introducción a las hormigas de la región neotropical. Bogotá: Instituto de Investigación de Recursos Biológicos Alexander Von Humboldt; 2003. p. 113-148.

Toranza C, Brazeiro A, Maneyro R. Anfibios amenazados de Uruguay: efectividad de las áreas protegidas ante el cambio climático. Ecología Austral 2016; 26: 138-149.

Unión Internacional para la Conservación de la Naturaleza y de los Recursos Naturales - UICN. Adaptación basada en ecosistemas: una respuesta al cambio climático. Quito: UICN; 2012.

Uribe, E. El cambio climático y sus efectos en la biodiversidad en América Latina. Santiago: Comisión Económica para América Latina y el Caribe; 2015. 86 p.

Varón EH, Hanson P, Longino J, Borbón O, Carballo M, Hilje L. Distribución espacio-temporal de hormigas en un gradiente de luz, dentro de un sistema agroforestal de café, en Turrialba, Costa Rica. Revista de Biología Tropical 2007; 55(3-4): 943-956. http://dx.doi.org/10.15517/rbt. v55i3-4.5968. PMid:19086397.

Zabala G, Arango L, Chacón P. Diversidad de hormigas (Hymenoptera: Formicidae) en un paisaje cafetero de Risaralda, Colombia. Revista Colombiana de Entomologia 2013; 39(1): 141-149. 